\title{
KEPEMIMPINAN DAN PENDIDIKAN ISLAM
}

\author{
Habibur Rahman, Raima Selviana \\ Universitas Trunojoyo Madura
}

\begin{abstract}
Leadership is a conscious effort carried out by someone (leader) to be able to realize the goals of the organization through other people by providing motivation so that other people want to implement it, and for that it requires a balance between the individual needs of the implementers. A leader must understand and understand the basics of leadership to be a leader, both in a small scope, such as family, discussion leaders, etc. as well as leaders in a large scope such as organizational leaders, religious leaders, country leaders and so on. But there are several factors for the emergence of leadership: first, the factors of situation and condition; second, the ability factor; third, heredity; fourth, the appointment factor; fifth, the factor of interest. Education is a process of guidance, educating that is given intentionally to students by adults to achieve the goals of education itself. Islamic education is the formation of personality to become a human being with moral character so that in everyday life to get happiness, peace, and can reflect the behavior according to Islamic shari'a which originates in the Qur'an, Sunnah Rasul and Ijtihad. Educational leadership is the ability to drive the implementation of education to achieve educational goals. This understanding is in line with the angle of leadership philosophy which basically upholds the principle of humanity.
\end{abstract}

Keywords: Leadership, Education

\section{PENDAHULUAN}

Pandangan yang mendasari setiap aktifitas pemimpin dalam kepemimpinannya baik dalam penyusunan perencanaan maupun pelaksanaan di lembaga, atau tempat yang dipimpinnya. Karena pemimpin sangat dibutuhkan dalam suatu organisasi kelompok individu sebagai pembimbing, motivator, dan penggerak yang menyebabkan orang lain bertindak sesuai dengan tujuan yang akan dicapai. Seseorang dapat menduduki jabatan pemimpin biasanya disebabkan oleh berbagai faktor, di antaranya: a) Faktor Situasi dan Kondisi, b) Faktor Kemampuan, c) Faktor Keturunan, d) Faktor Pengangkatan (Penunjukan), dan e) Faktor Kepentingan.

Kepemimpinan (leadership) merupakan pembahasan yang selalu menarik, karena ia merupakan salah satu faktor penting dan menentukan keberberhasilan atau gagalnya suatu organisasi dalam mencapai tujuannya. Pentingnya hal itu ditandai dengan berlangsungnya berbagai jenis kegiatan pelatihan (training) kepemimpinan, terutama bagi 
individu yang dipersiapkan untuk menjadi pemimpin suatu organisasi atau lembaga. Dan sangat maklum bahwa setiap organisasi apapun jenisnya pasti memiliki dan memerlukan seorang pimpina tertinggi (pimpinan puncak) dan atau manajer tertinggi (top manajer) yang harus menjalankan kepemimpinan dan manajemen.

Guru sebagai pemimpin pendidikan bagi murid. Guru dalam Islam adalah orang yang bertanggungjawab terhadap perkembangan anak didik dengan mengupayakan seluruh potensinya, baik potensi afektif, potensi kognitif, maupun potensi psikomotorik. Guru juga berarti orang dewasa yang bertanggungjawab memberikan pertolongan pada anak didik dalam perkembangan jasmani dan rohaninya agar menacapai tingkat kedewasaan, serta mampu berdiri sendiri dalam memenuhi tugasnya sebagai hamba Allah.

\section{TINJAUAN PUSTAKA}

\section{Kepemimpinan}

"Menurut Griffin dan Ebert, kepemimpinan (leadership) adalah proses memotivasi orang lain untuk mau bekerja dalam rangka mencapai tujuan yang telah ditetapkan. Lindsay dan Patrick dalam membahas "Mutu Total dan Pembangunan Organisasi" mengemukakan bahwa kepemimpinan adalah suatu upaya merealisasikan tujuan perusahaan dengan memadukan kebutuhan para individu untuk terus tumbuh berkembang dengan tujuan organisasi. Perlu diketahui bahwa para individu merupakan anggota dari perusahaan. Peterson at. all, mengatakan bahwa kepemimpinan merupakan suatu kreasi yang berkaitan dengan pemahaman dan penyelesaian atas permasalahan internal dan eksternal organisasi. Kepemimpinan dari segi istilah dapat didefisinikan sebagai proses mempengaruhi orang lain untuk berbuat guna mewujudkan tujuan-tujuan yang sudah di tentukan. Kepemimpinan selalu melibatkan upaya seseorang (pemimpin) untuk mepengaruhi perilaku seseorang pengikut atau para pengikut dalam suatu situasi. Kepemimpinan adalah proses menggerakkan manusia untuk meraih tujuan. Kepemimpinan memiliki tiga unsur: 1) Adanya tujuan yang menggerakkan manusia, 2) Adanya sekelompok orang, 3) Adanya pemimpin yang mengarahkan dan memberikan pengaruh kepada manusia.

Dari beberapa definisi kepemimpinan di atas dapat disimpulkan bahwa kepemimpinan merupakan usaha sadar yang dilakukan seseorang (pemimpin) dalam proses 
mempengaruhi, memotivasi, dan menyebabkan seseorang atau kelompok orang untuk berbuat guna mengarah pada tujuan yang sudah ditentukan.

\section{Konsep Dasar Kepemimpinan}

Menurut Griffin dan Ebert, kepemimpinan (leadership) adalah proses memotivasi orang lain untuk mau bekerja dalam rangka mencapai tujuan yang telah ditetapkan. Lindsay dan Patrick dalam membahas "Mutu Total dan Pembangunan Organisasi" mengemukakan bahwa kepemimpinan adalah suatu upaya merealisasikan tujuan perusahaan dengan memadukan kebutuhan para individu untuk terus tumbuh berkembang dengan tujuan organisasi. Perlu diketahui bahwa para individu merupakan anggota dari perusahaan. Peterson at. all, mengatakan bahwa kepemimpinan merupakan suatu kreasi yang berkaitan dengan pemahaman dan penyelesaian atas permasalahan internal dan eksternal organisasi. Kepemimpinan dari segi istilah dapat didefisinikan sebagai proses mempengaruhi orang lain untuk berbuat guna mewujudkan tujuan-tujuan yang sudah di tentukan. Kepemimpinan selalu melibatkan upaya seseorang (pemimpin) untuk mepengaruhi perilaku seseorang pengikut atau para pengikut dalam suatu situasi. Kepemimpinan adalah proses menggerakkan manusia untuk meraih tujuan. Kepemimpinan memiliki tiga unsur: 1) Adanya tujuan yang menggerakkan manusia, 2) Adanya sekelompok orang, 3) Adanya pemimpin yang mengarahkan dan memberikan pengaruh kepada manusia.

Kepemimpinan (leadership) merupakan pembahasan yang selalu menarik, karena ia merupakan salah satu faktor penting dan menentukan keberberhasilan atau gagalnya suatu organisasi dalam mencapai tujuannya. Pentingnya hal itu ditandai dengan berlangsungnya berbagai jenis kegiatan pelatihan (training) kepemimpinan, terutama bagi individu yang dipersiapkan untuk menjadi pemimpin suatu organisasi atau lembaga. Dan sangat maklum bahwa setiap organisasi apapun jenisnya pasti memiliki dan memerlukan seorang pimpina tertinggi (pimpinan puncak) dan atau manajer tertinggi (top manajer) yang harus menjalankan kepemimpinan dan manajemen.

Kepemimpinan berasal dari kata dasar "pimpin" yang memiliki arti bimbing atau tuntun. Dari kata Pimpin lahirlah kata kerja "memimpin” yang artinya membimbing atau menuntun. Sedangkan kata kepemimpinan sendiri berarti kegiatan menuntun, memandu dan menunjukkan jalan. Secara terminologi banyak ahli yang memberikan definisi. 
Menurut Stogdill, kepemimpinan diartikan sebagai kemampuan menggerakkan atau memotivasi sejumlah orang agar secara serentak melakukan kegiatan yang sama dan terarah pada pencapaian tujuan. Selanjutnya Robert Kreither dan Angelo Kinicki yang dikutip Haidar Imam Bukhori mengatakan bahwa kepemimpinan adalah upaya mempengaruhi anggota untuk mencapai tujuan organisasi secara sukarela.

Pengertian ini menekankan pada kemampuan pemimpin yang tidak memaksa dalam menggerakkan anggota organisasi agar melakukan kegiatan yang terarah pada tujuan organisasi. Dalam pengertian yang senada Gibson yang dikutip Haidar Imam Bukhori juga mengatakan kepemimpinan adalah upaya menggunakan berbagai jenis pengaruh yang bukan paksaan untuk memotivasi anggota organisasi agar mencapai tujuan tertentu. Memotivasi berarti dilakukan sebagai kegiatan mendorong anggota organisasi untuk melakukan kegiatan tertentu tanpa memaksa dan mengarah pada tujuan. Kegiatan mendorong merupakan usaha menumbuhkan motivasi instrinsik, yaitu dorongan yang tumbuh dari dalam diri anggota organisasi yang berupa kesadaran terhadap peranan dan pentingnya kegiatan dalam usaha mencapai tujuan organisasi.

Pengertian yang agak berbeda dikemukakan oleh Pondy. Dia menyatakan bahwa kepemimpinan sebagai kemampuan untuk menjadiakn suatu aktifitas bermakna, tidak untuk merubah perilaku, namun memberi pemahanan kepada pihak lain tentang apa yang mereka lakukan. Dari sekian banyak definisi kiranya dapat disimpulkan bahwa kepemimpinan diartikan sebagai kegiatan untuk mempengaruhi orang-orang yang diarahkan terhadap pencapaian tujuan organisasi dengan seorang pemimpin puncak sebagai figur sentral yang memiliki wewenag dan tanggung jawab dalam mengefektifkan organisasi tersebut. Karenanya kepemimpinan menurut Robbins selalu terkait dengan kemampuan mempengaruhi orang lain dan kemampuan mengambil keputusan.

\section{Pendidikan Islam}

Pengertian pendidikan dilihat dari istilah adalah bimbingan atau pertolongan yang diberikan dengan sengaja terhadap anak didik oleh orang dewasa agar ia menjadi dewasa. Definisi lain dari pendidikan adalah suatu proses penyiapan generasi muda untuk menjalankan kehidupan dan memenuhi tujuan hidupnya secara lebih efektif dan efisien. Sering ditafsirkan usaha pendidikan sebagai bimbingan kepada anak untuk mencapai kedewasaan yang kelak mampu berdiri sendiri dan mengejar cita-citanya. Titik akhir 
kegiatan mendidik adalah tercapainya kedewasaan. Pendapat ini dipelopori oleh Langeveld sebagai anak dari jamannya dan lingkungannya. Beliau dibesarkan dalam kebudayaan Barat yang menekankan sikap individualisme. Pengertian pendidikan seperti yang lazim dipahami sekarang belum terdapat di zaman Nabi. Tetapi usaha dan kegiatan yang dilakukan oleh Nabi dalam menyampaikan seruan agar dengan berdakwah, menyampaikan ajaran, memberi contoh, melatih keterampilan berbuat, memberi motivasi dan menciptakan lingkungan yang mendukung pelaksanaan ide pembentukan pribadi muslim itu, telah mencakup arti pendidikan dalam pengertian sekarang.

Langgulung menjelaskan bahwa pendidikan dapat dilihat dari tiga segi, pertama pendidikan dilihat dari segi individu artinya individu secara fitri dibekali kemampuan (Abilites) yang masing-masing individu memiliki derajat kemampuan yang berbeda-beda, maka pendidikan di sini diartikan sebagai proses untuk mengembangkan dan menentukan kemampuan-kemampuan (pengembangan potensi) yang tentunya juga lewat latihan-latihan atau pembinaan-pembinaan yang dapat dan mampu mengembangkan potensinya itu. Kedua, dilihat dari segi pandangan masyarakat bahwa manusia memperoleh pengetahuan dengan mencarinya pada alam di luar pelajar, maka pendidikan di sini diartikan sebagai proses pewaris dan budaya atau dengan kata lain masyarakat mempunyai nilai-nilai budaya yang ingin disalurkan dari generasi ke generasi agar identitas masyarakat tersebut tetap terpelihara. Juga dilihat dari segi pendidikan sebagai proses memberi dan mengambil antara manusia dan lingkungannya, atau dengan kata lain pendidikan sebagai proses interaksi (hubungan timbal balik) antara potensi individu dan budaya. Dapat disimpulkan bahwa pendidikan adalah proses bimbingan, mendidik yang diberikan dengan sengaja terhadap anak didik oleh orang dewasa guna mencapai tujuan dari pendidikan itu sendiri.

\section{Pengertian Pendidikan Islam}

Pendidikan Islam menurut Hasan Langgulung, bahwa pendidikan Islam adalah suatu proses penyiapan generasi muda untuk mengisi peranan, mentransfer ilmu pengetahuan dan nilai-nilai Islam yang diselaraskan dengan fungsi manusia untuk beramal di dunia dan memetik hasilnya di akherat. Pendapat Al-Ghazali itu didukung oleh M. Athiyah Abrasyi mengatakan pendidikan budi pekerti adalah jiwa dari pendidikan Islam (pendidikan yang dikembangkan oleh kaum muslimin), dan Islam telah menyimpulkan bahwa pendidikan budi pekerti dan akhlak adalah jiwa pendidikan Islam. Mencapai suatu 
akhlak yang sempurna adalah tujuan sebenarnya dari pendidikan. Menurut Ahmad D. Marimba bahwa pendidikan Islam adalah usaha yang diarahkan kepada pembentukan kepribadian anak didik sesuai dengan ajaran Islam, memikirkan, memutuskan, dan berbuat sesuai dengan ajaran Islam. Pengertian pendidikan Islam tersebut di atas sesuai dengan yang disampaikan oleh Zuhaiini dkk, pendidikan Islam adalah usaha yang diarahkan kepada pembentukan kepribadian anak didik sesuai dengan ajaran Islam, memikirkan, memutuskan, dan berbuat sesuai dengan ajaran Islam. Ramayulis berpendapat bahwa pendidikan Islam adalah suatu proses edukatif yang mengarahkan kepada pembentukan akhlak atau kepribadian.

Jadi, dari beberapa pengertian tentang pendidikan Islam tersebut di atas dapat disimpulkan bahwa pendidikan Islam adalah pembentukan kepribadian untuk menjadi manusia yang berakhlakul karimah agar dalam kehidupan sehari-hari mendapatkan kebahagiaan, ketenteraman, serta dapat mencerminkan perilaku sesuai syari'at Islam.

\section{Dasar-dasar Pendidikan Islam}

Setiap usaha, kegiatan dan tindakan yang sengaja untuk mencapai suatu tujuan harus mempunyai landasan. Begitu juga dengan pendidikan islam yang menurut Ahmadi, landasan (dasar) tersebut adalah nilai-nilai yang luhur yang besifat transendental, universal dan eksternal.

Dasar-dasar pendidikan Islam bersumber pada Al-Qur'an, Sunnah Rasul yang dapat dikembangkan dengan Ijtihad.

a. Al-Qur'an

Al-Qur'an sebagai landasan dasar pendidikan Islam yang di dalamnya terkandung dua prinsip besar yaitu yang berhubungan dengan masalah keimanan yang disebut aqidah, dan yang berhubungan dengan amal yang disebut syari'ah. ${ }^{27}$

Kedudukan Al-Qur'an sebagai sumber pokok pendidikan Islam dapat dipahami dari ayat Al-Qur'an itu sendiri. Allah berfirman dalam Al- Qu'an surat An-Nahl ayat 64:

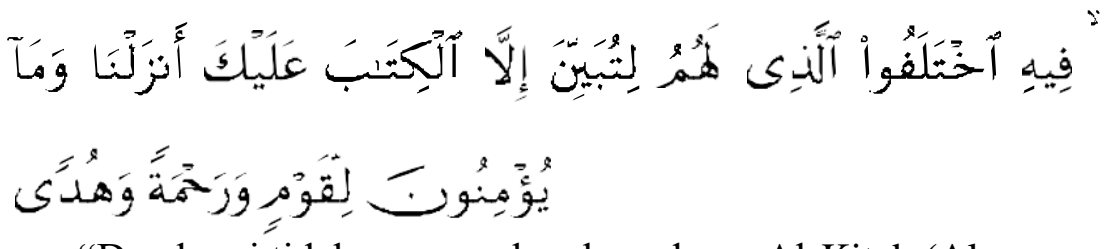

Artinya: "Dan kami tidak menurunkan kepadamu Al-Kitab (Al

-Qur'an) ini melainkan agar kamu dapat menjelaskan kepada 
mereka perselisihan itu dan menjadi petunjuk dan rahmat bagi kaum yang beriman" (QS. An-Nahl: 64)

Sebagai contoh dapat dibaca kisah Lukman mengajari anaknya dalam surat Lukman ayat 12-19. Cerita itu menggariskan prinsip materi pendidikan yang terdiri dari masalah iman, akhlak ibadat, sosial dan ilmu pengetahuan. Ayat lain menceritakan tujuan hidup dan tentang nilai sesuatu kegiatan dan amal soleh. Itu berarti bahwa kegiatan pendidikan harus mendukung tujuan hidup tersebut. Oleh karena itu pendidikan islam harus menggunakan Al-Qur'an sebagai sumber utama dalam merumuskan berbagai teori tentang pendidikan Islam. Dengan kata lain, pendidikan Islam harus berlandaskan ayatayat Al-Qur'an yang penafsian dapat dilakukan berdasarkan ijtihad disesuaikan dengan perubahan dan pembaharuan.

b. Sunnah

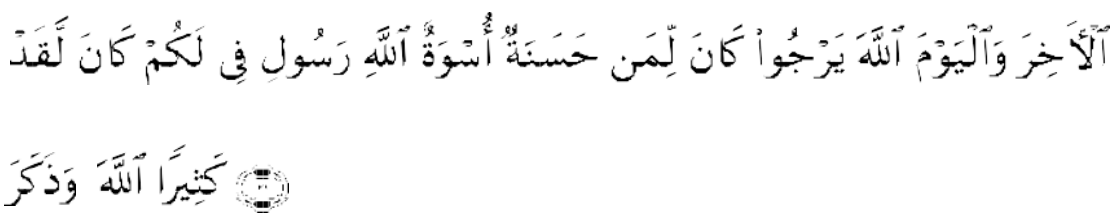

Artinya: "Sungguh, telah bagi orang yang mengharap (rahmat)

Dasar yang kedua selain Al -Qu'an adalah sunnah Rosulullah. Amalan yang dikerjakan oleh Rosulullah Saw dalam proses perubahan sikap hidup sehari-hari menjadi sumber utama pen didikan Islam karena Allah SWT menjadikan Muhammad sebagai teladan bagi umatnya. Allah berfirman dalam Al-Qur'an surat Al-Ahzab ayat 21:

Allah dan (kedatangan )hari kiamat dan yang banyak mengingat

$$
\text { Allah". (Qs. Al-Ahzab : 21) }
$$

c. Ijtihad

Ijtihad dibidang pendidikan ternyata semakin perlu sebab ajaran Islam ang terdapat dalam Al-Qur'an dan Sunnah adalah bersifat pokokpokok dan prinsip-prinsipnya saja. Bila ternyata ada yang agak terperinci, maka perincian itu adalah sekedar contoh dalam menerapkan yang prinsip itu.

Dari beberapa uraian di atas jelas bahwa dasar pendidikan Islam tidak hanya bersumber pada Al-Qur'an dan As-Sunnah, namun ijtihad juga dapat dijadikan sumber dasar pendidikan. 
2. Tujuan Pendidikan Islam di Indonesia

Sebelum menjelaskan tujuan pendidikan Islam di Indonesia, perlu penulis kemukakan terlebih dahulu beberapa tujuan pendidikan, antara lain: Tujuan Umum ialah tujuan yang akan dicapai dengan semua kegiatan pendidikan, baik dengan pengajaran atau dengan cara lain. Tujuan itu meliputi seluruh aspek kemanusiaan yang meliputi sikap, tingkah laku, penampilan, kebiasaan dan pandangan. Tujuan umum ini berbeda pada setiap tingkat umur, kecerdasan, situasi, dan kondisi dengan kerangka yang sama. Bentuk insan kamil dengan pola takwa harus dapat tergambar pada pribadi seseorang yang

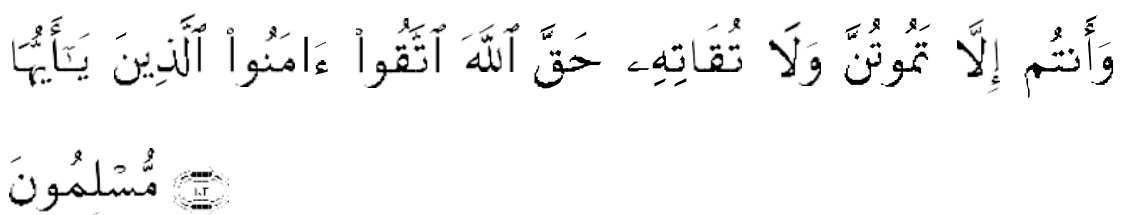

sudah di didik, walaupun dalam ukuran kecildan mutu pendidikan yang rendah, sesuai dengan tingkat-tingkat tersebut. b) Tujuan Akhir Pendidikan Islam itu dapat di pahami dalam firman Allah surat Ali Imron ayat 102:1

Artinya: "Wahai orang-orang yang beriman, bertakwalah kamu kepada Allah dengan sebenar-benarnya takwa; dan janganlah kamu mati kecuali dalam keadaan muslim (menurut ajaran Islam)”. (Qs. Ali Imran : 102)

Pendidikan Islam di Indonesia haruslah berorientasi pada tujuan umum pendidikan Islam sebagaimana yang telah dijelaskan sebelumnya, akan tetapi disegi lain harus pula berorientasi pada tujuan pendidikan nasional. Tujuan pendidikan nasional dirumuskan dengan mendasarkannya kepada pandangan hidup bangsa yaitu Pancasila, sehingga diharapkan lembaga pendidikan Islam di Indonesua dapat melahirkan manusia muslim yang Pancasilais. Pemerintah Indonesia telah menyusun dan merumuskan tujuan pendidikan yang dapat dijadikan sebagai arah dalam proses pendidikan pada setiap lembaga pendidikan di Indonesia. Tujuan ini telah digariskan dalam Undang-Undang RI No. 20 tahun 2003 tentang sistem pendidikan nasional menyebutkan bahwa tujuan pendidikan nasional adalah mengembangkan potensi peserta didik agar menjadi manusia yang beriman, bertaqwa kepada Tuhan Yang Maha Esa, berakhlak mulia, sehat, berilmu, cakap, kreatif, mandiri, dan menjadi warga negara yang demokratis dan bertanggungjawab. 
Apabila dianalisa secara mendalam, sebenarnya tujuan umum pendidikan Islam dan tujuan pendidikan nasional Indonesia pada hakekatnya tidak bertentangan bahkan mempunyai titik persamaan, apabila pendidikan nasional diletakkan secara proposional dalam rangka pendidikan nasional, maka pendidikan Islam dapat menciptakan insan yang beriman, bertaqwa seperti yang dirumuskan di dalam UU RI No. 20 tahun 2003 tersebut di atas, dan sekaligus berarti mendidik insan Pancasila dan insan yang beragama.

\section{Kepemimpinan Pendidikan}

Berbicara tentang kepemimpinan pendidikan, hendaklah kita berusaha memahami bahwa dalam pelaksanaan tugas itu ada seorang yang berfungsi sebagai pemimpin. Ia adalah orang yang dapat bekerjasama dengan orang lain dan yang dapat bekerja untuk orang lain. Siapakah yang sebenarnya dapat disebut pemimpin pendidikan? Tiap-tiap orang yang merasa terpanggil untuk melaksanakan tugas memimpin di dalam lapangan pendidikan, misalnya orang tua di rumah, guru di sekolah, kepala kantor Departemen Pendidikan dan Kebudayaan, serta pengawas pendidikan di Kantor Pembinaan Pendidikan dan di daerah pelayanannya, juga pendidik lain. Kepemimpinan sangat dibutuhkan dalam pembinaan pendidikan.

Ki Hadjar Dewantara, seorang bapak Taman Siswa, menganggap pendidikan sebagai daya upaya untuk mewujudkan bertumbuhnya budi pekerti, kekuatan batin, karakteristik, pikiran (intelek) dan tubuh anak untuk memajukan kehidupan anak didik selaras dengan dunianya. Apabila pengertian kepemimpinan dipadukan dengan pengertian pendidikan, maka akan muncul pengertian kepemimpinan pendidikan. Dirawat dan kawan-kawan memberikan definisi kepemimpinan pendidikan sebagai satu kemampuan dan proses mempengaruhi, membimbing, mengkoordinir dan menggerakkan orang-orang lain yang ada hubungannya dengan pengembangan ilmu pendidikan dan pelaksanaan pendidikan dan pengajaran, agar supaya kegiatan-kegiatan yang diajukan dapat lebih efisien dan efektif di dalam pencapaian tujuan-tujuan pendidikan dan.

3. Fungsi Kepemimpinan Pendidikan

a. Fungsi pemimpin yang bertalian dengan tujuan yang hendak dicapai, antara lain terdiri dari: 1) Pemimpin berfungsi memikirkan dan merumuskan dengan teliti tujuan kelompok serta menjelaskan supaya anggota dapat bekerjasama mencapai tujuan itu; 2) Pemimpin berfungsi memberi dorongan kepada anggota-anggota kelompok untuk 
menganalisis situasi supaya dapat dirumuskan rencana kegiatan kepemimpinan yang dapat memberi harapan yang baik; 3) Pemimpin berfungsi membantu anggota kelompok dalam mengumpulkan keterangan yang perlu supaya dapat mengadakan pertimbangan yang sehat,; 4) Pemimpin berfungsi menggunakan kesanggupan dan minat khusus anggota kelompok; 5) Pemimpin berfungsi memberi dorongan kepada setiap anggota kelompok untuk melahirkan perasaan dan pikirannya dan memilih buah pikiran yang baik dan berguna dalam perencanaan masalah yang dihadapi oleh kelompok; 6) Pemimpin berfungsi memberi kepecayaan dan menyerahkan tanggungjawab kepada anggota dalam melaksanakan tugas, sesuai dengan kemampuan masing-masing demi kepentingan bersama.

b. Fungsi pemimpin yang bertalian dengan penciptaan suasana pekerjaan yang sehat dan menyenangkan sambil memeliharanya, antara lain: 1) Memupuk dan memelihara kesediaan kerjasama di dalam kelompok demi tercapainya tujuan bersama; 2) Menanamkan dan memupuk perasaan pada anggota masing-masing bahwa mereka termasuk dalam kelompok dapat dibentuk melalui penghargaan terhadap usahausahanya dan sifat yang ramah tamah, gembira dari pemimpin akan mempengaruhi anggota-anggota dan mereka pasti akan menirunya; 3) Meungusahakan suatu tempat pekerjaan yang menyenangkan; 4) Mempergunakan kelebihan-kelebihan yang terdapat pada pimpinan untuk memberi sumbangan dalam kelompok menuju pencapaian tujuan bersama dan pimpinan dapat juga mengembangkan kesanggupankesanggupan anggota masing-masing, maka dengan demikian pemimpin ini akan diterima dan diakui secara wajar.

Guru sebagai pemimpin pendidikan bagi murid. Guru dalam Islam adalah orang yang bertanggungjawab terhadap perkembangan anak didik dengan mengupayakan seluruh potensinya, baik potensi afektif, potensi kognitif, maupun potensi psikomotorik. Guru juga berarti orang dewasa yang bertanggungjawab memberikan pertolongan pada anak didik dalam perkembangan jasmani dan rohaninya agar menacapai tingkat kedewasaan, serta mampu berdiri sendiri dalam memenuhi tugasnya sebagai hamba Allah. Allah berfirman dalam surat Ali Imran ayat 164:

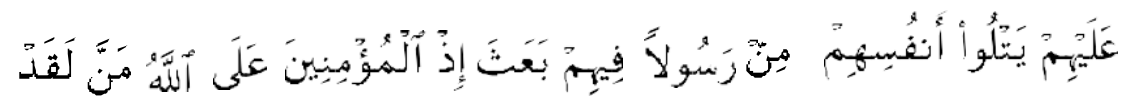




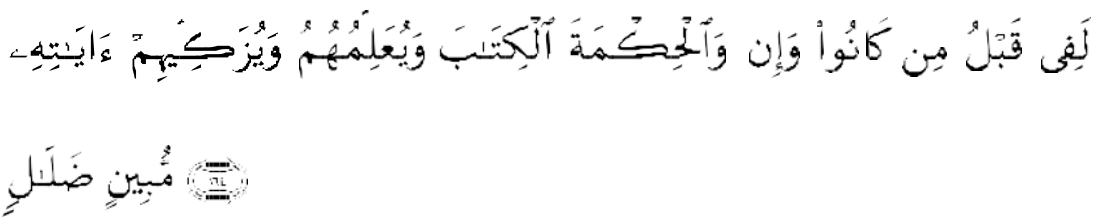

Artinya: "Sesungguhnya Allah telah memberikan karunia kepada orang yang beriman ketika Allah mengutus di antara mereka seorang Rasul dari golongan mereka sendiri yang membacakan kepada mereka ayat-ayat Allah, membersihkan jiwa mereka, dan mengajarkan kepada mereka al-kitab dan al- hikmah. Dan sesungguhnya sebelum kedatangan Nabi itu, mereka benar-benar dalam kesesatan yang nyata"(Qs. Ali Imran: 164 )

Dari ayat di atas, dapat ditarik kesimpulan yang utama bahwa tugas Rasulullah selain sebagai Nabi, juga sebagai pendidik (Guru). Oleh karena itu, fungsi utama guru menurut ayat tersebut adalah:1) Penyucian, yakni pengembangan, pembersihan dan pengangkatan jiwa kepada pencipta-Nya, menjauhkan diri dari kejahatan dan menjaga diri agar tetap berada pada fitrah; 2) Pengajaran, yakni pengalihan berbagai pengetahuan dan akidah kepada akal dan hati kaum Muslimin agar mereka merealisasikannya dalam tingkahlaku kehidupan.

Selain fungsi utama guru di atas, ada beberapa fungsi guru yang akan penulis kemukakan, antara lain: 1) Guru sebagai Pribadi Kunci. Kita mengetahui bahwa guru merupakan key person dalam kelas. Guru yang memimpin dan mengarahkan kegiatan belajar para siswanya. Guru yang paling banyak berhubungan dengan para siswa dibandingkan dengan melainkan juga dalam bidang non akademis. Dalam masyarakat kita "personal sekolah lainnya. Di depan mata anak-anak, guru adalah seseorang memiliki otoritas, bukan saja otoritas dalam bidang akademis, guru” dipandang sebagai orang yang harus "digugu dan ditiru" (dituruti dan ditiru). Pengaruh guru terhadap para siswanya sangat besar. Faktor-faktor imitasi, sugesti, identifikasi, dan simpati, misalnya memegang peran penting dalam interaksi sosial, 2) Guru sebagai Pengajar dan Pembimbing: a) Guru sebagai Pengajaran. Melalui bidang pendidikan, guru mempengaruhi berbagai aspek kehidupan, baik sosial, budaya, maupun ekonomi. Dalam keseluruhannya proes pendidikan, guru merupakan faktor utama yang bertugas sebagai pendidik. Guru memegang berbagai jenis peranan yang mau tidak mau harus dilaksanakannya sebagai 
guru. b) Guru sebagai Pembimbing. Peran guru sebagai pembimbing, seorang guru harus menyelenggarakan bimbingan kelompok atau individu bekerjasama dengan masyarakat dan lemabaga-lembaga lainnya untuk membantu memecahkan masalah siswa.

4. Tipe-tipe Kepemimpinan Pendidikan

Sesuai dengan situasi sekarang dimana kita berada di tengah-tengah perjuangan menuju tujuan pendidikan tidak lepas dan sangat membutuhkan tipe-tipe pemimpin, sebagai pemimpin pendidikan yang official leader. Ada beberapa pendapat mengenai tipe-tipe kepemimpinan, antara lain: a) Kepemimpinan Otokratis. Seorang pemimpin yang otokratis memperlihatkan kekuasaannya,

ingin berkuasa. Ia berpendapat bahwa tanggungjawabnya sebagai pemimpin besar sekali. Hanya dialah yang bertanggungjawab dalam kepemimpinannya. Maju mundurnya organisasi yang dipimpinnya sangat bergantung kepadanya. menggembirakan anggota. Misalkan, di sekolah guru-guru akan bersifat acuh tak acuh atau memberontak, kecuali guru yang menjadi sahabat atau kesayangannya; b) Kepemimpinan Pseudo-Demokatis. Seorang pemimpin yang bersifat pseudoDemokratis memakai "topeng". Ia pura-pura memperlihatkan sifat demokratis di dalam kepemimpinannya. Ia memberi hak dan kuasa kepada anggotanya (guru) untuk menetapkan dan memutuskan sesuatu, tetapi sesungguhnya ia bekerja dengan perhitungan. Ia mengatur siasat agar kemauannya terwujud kelak. Bagi pemimpin seperti itu berarti memberi bimbingan dengan lemah-lembut dalam mengejarkan hal-hal yang dikehendakinya supaya mereka melakukannya; c) Kepemimpinan Laissez- Faire. Pemimpin pada tipe ini menghendaki supaya kepada bawahannya diberikan banyak kebebasan. Pemimpin bersikap acuh tak acuh terhadap tugas dan kewajibannya. Ia beranggapan bahwa dengan memberi kebebasan kepada guru-guru itu, mereka akan lebih bersemangat dan bergembira dalam melaksanakan tugas mereka. Ia telah memberi pengertian yang salah dan kacau, d) Kepemimpinan Demokratis. Macam kepemimpinan yang baik dan yang sesuai dewasa ini ialah kepemimpinan demokratis. Pemimpin menghormati dan menghargai pendapat anggotanya. Pemimpin tidak melaksanakan tugasnya sendiri. Ia berbijaksana di dalam pembagian pekerjaan dan tanggungjawab. Dapat dikatakan bahwa tanggungjawab terletak pada pundak dewan guru seluruhnya termasuk pemimpin sekolah. 
5. Syarat-syarat Kepribadian Bagi Seorang Pemimpin Pendidikan

Kualifikasi kepribadian guru dipandang sangat penting oleh sebab itu guru (pendidik) bukan saja melaksanakan pendidikan, ia juga dituntut dapat memperbaiki pendidikan yang telah terlanjur salah diterima anak sekaligus mengadakan pendidikan ulang. Kemudian AlGhazali mengemukakan syarat-syarat kepribadian seorang pendidik, sebagai berikut: a) Sabar menerima masalah-masalah yang ditanyakan murid dan harus diterima baik;

Senantiasa bersifat kasih dan tidak pilih kasih; c) Jika duduk harus sopan dan tunduk, tidak riya' (pamer); d) Tidak takabbur, kecuali terhadap orang yang dhalim, dengan maksud mencegah dari tindakannya; e) Bersikap tawadhu' dalam pertemuan-pertemuan. Kriteria yang di terapkan oleh Departemen Pendidika Amerika Serikat menyimpulkan bahwa guruguru yang baik di gambarkan dengan ciri-ciri sebegai berikut: a) Guru yang waspada secara profesional. Ia berusaha untuk menjadikan masyarakat sekolah menjadi tempat yang paling baik bagi anak-anak muda; b) Mereka yakin akan nilai atau manfaat pekerjaannya, sehingga terus memperbaiki dan meningkatkan mutu pekerjaannya; c) Mereka tidak lekas tersinggung oleh larangan-larangan dalam hubungannya dengan kebebasan pribadi yang dikemukakan oleh beberapa orang untuk menggambarkan profesi keguruan; d) Mereka memiliki seni dalam hubungan-hubungan manusia yang diperolehnya dari pengamatannya tentang bekerjanya psikologi, biologi, dan antropologi kultural di dalam kelas; e) Mereka berkeinginan untuk terus tumbuh. Mereka sadar bahwa pengaruhnya, sumber-sumber manusia dapat berubah nasibnya.

6. Faktor-faktor Yang Mempengaruhi Kepemimpinan Pendidikan

Seorang yang menduduki profesi pemimpin pendidikan, dalam menjalankan tugas kepemimpinanya dipengaruhi oleh faktor-faktor berikut antara lain: 1) Faktor-faktor legal sebagai pengaruh dalam kepemimpinan. Seseorang yang menduduki jabatan pemimpin pendidikan akan berhadapan dengan peraturan-peraturan formal dari instansi struktural yang berada di atasnya. Di Indonesia, falsafah Pancasila, UUD 1945, keputusan Presiden, keputusan Menteri, dan Undang-Undang lainnya akan mempengaruhi pola kepemimpinan pendidikan; 2) Kondisi sosial ekonomi dan konsep-konsep pendidikan sebagai pengaruh dalam kepemimpinan. Faktor ini terdiri atas dua macam, yaitu: a) Kondisi Sosial-Ekonomi yang memungkinkan tersedianya sumber-sumber dan fasilitas pendidikan. Bantuan individu maupun masyarakat terhadap pendidikan dalam hal fasilitas akan membantu juga memperlancar jalannya pendidikan; b) Konsep tujuan pendidikan para pemimpin 
masyarakat dan para warga pada umumnya akan berpengaruh terhadap pola kepemimpinan; 3) Hakekat dan atau Ciri Sekolah sebagai Pengaruh Kepemimpinan. Faktor ini berkaitan dengan ciri dan atas hakikat para staf, para murid dan jenis sekolah akan mempengaruhi kepemimpinan kepala sekolah sebagai pemimpin pendidikan. Sistem administrasi, kurikulum yang digunakan dan pendekatan yang digunakan dalam sistem pendidikan akan berpengaruh juga terhadap sistem kepemimpinan pendidikan; 4) Kepribadian Pemimpin Pendidikan dan Latihan-latihan sebagai Faktor yang Mempengarui Kepemimpinan. Tidak dapat ingkari bahwa individu itu sendiri membawa sesuatu dalam jabatanya. Energinya, logalitas, pandangan hidupnya dan atrobut atributnya profesional yang melekat padanya akan berpengaruh terhadap sistem kepimpinan; 5) Perubahanperubahan yang Terjadi dalam Teori Pendidikan sebagai Faktor yang Mempengaruhi Kepemimpinan. Tugas kepemimpinan pendidikan dipengaruhi oleh berbagi perubahan teori dan metode aktifitas belajar.Konsep-konsep pertubuhan dan perkembangan anak membawa implikasi terhadap produser pengajaran di kelas. Hal ini akan berbeda dengan sepuluh tahun yang lalu atau lebih; 6) Kepribadian dan Training Kepala Sekolah Mempengaruhi Kepemimpinan. Adalah suatu kenyataan bahwa individu itu sendiri membawa sesuatu dalam pekerjaan. Tenaganya, loyalitasnya, dan lain-lain atribut personal maupun profesional akan merupakan faktor signifikan yang berpengaruh terhadap jenis kepemimpinannya di sekolah. Oleh sebab itu suatu kewajiban moral dan tentunya profesional di Indonesia untuk menuntut adanya kualifikasi profesional untuk para kepala sekolah.

\section{KESIMPULAN}

Seorang pemimpin tentunya harus memahami serta mengerti akan dasar- dasar kepemimpinan untuk dapat menjadi pemimpin, baik dalam lingkup yang kecil, seperti keluarga, pemimpin diskusi, dan lain-lain maupun pemimpin dalam lingkup yang besar seperti pemimpin organisasi, pemimpin agama, pemimpin negara dan sebagainya. Namun ada beberapa faktor munculnya kepemimpinan: pertama, faktor situasi dan kondisi; kedua, faktor kemampuan; ketiga, faktor keturunan; keempat, faktor pengangkatan; kelima, faktor kepentingan. Pendidikan Islam adalah pembentukan kepribadian untuk menjadi manusia yang berakhlakul karimah agar dalam kehidupan sehari-hari mendapatkan kebahagiaan, 
ketenteraman, serta dapat mencerminkan perilaku sesuai syari'at Islam yang bersumber pada Al-Qur'an, Sunnah Rasul dan Ijtihad.

\section{DAFTAR PUSTAKA}

Achmad. 1992. Islam Sebagai Paradigma Ilmu Pendidikan. Yogyakarta: Aditya Media,

Bukhori, Haidar Imam. 2003. Kepemimpinan Mengefektifkan Organisasi.Yogyakarta: Gajah Mada Univesity Press.

Daradjat, Zakiyah, dkk. 1996. Ilmu Pendidikan Islam. Jakarta: Bumi Aksara,.

Darwis, Djamaluddin. 2006. Dinamika Pendidikan Islam Sejarah; Ragam dan Kebudayaan .Semarang : Rasail

Dubrin, Andrew J. 2005.The Complete Ideal's Guides Leadership. Jakarta: Prenada Media

E. Mulyasa. 2002. Manajemen Berbasis Sekolah: Konsep, Strategi dan Implementasi. Bandung; Rosdakarya.

Faqih, Ainur Rohim. 2001. Kepemimpinan Islam. Yogyakarta: UII Press

Griffin W. Ricky dan Ebert J. Ronald, 1999. Business. New Jersey: Prentice Hall International Inc,.

Hamalik, Oemar. 2001. Psikologi Belajar dan Mengajar. Bandung: Sinar Baru Algensindo,.

I.L. Pasaribu, dkk. 1982. Pendidikan Nasional; Tinjauan Pedagogik Teoritis. Bandung: Tarsito

Indrafachrudi, Soekarto. 1993. Mengantar Bagaimana Memimpin Sekolah Yang Baik. Jakarta: Ghalia Indonesia.

Langgulung, Hasan, 1988. Pendidikan Islam Menghadapi Abad 21. Jakarta: Al-Husna,.

Lindsay M. William dan Patrick A. Joseph. 1997.Total Quality and Organization Development. Florida: St. Lucie Press,.

Manullang. 2001. Manajemen Sumber Daya Manusia Edisi Pertama. Yogyakarta: PT. BPFE

Marimba, Ahmad D. Pengantar Filsafat Islam. Al-Ma'arif, Bandung, 1992.

Nurdin, Muhammad. Kiat Menjadi Guru Profesional. Yogyakarta: Prismasophie, 2004.

Pamuji. Kepemimpinan Pemerintah di Indonesi. Jakarta: Bumi Aksara , 1995.

Peterson W. Marvin, at. all. Planning and Management for a Changing Environment. San Francisco: Jossey-Bass Publishers, 1997.

Ramayulis. , 1998. Ilmu Pendidikan Islam. Jakarta: Kalam Mulia

Siagian, Sondang P. 1988. Teori dan Praktek Kepemimpinan. Jakarta: PT Bina Aksara,

Soetopo, Hendiyat. 1984. Kepemimpinan dan Supervisi Pendidikan. Malang: Bina Aksara,

Sukamto. 1999. Kepemimpinan Kyai dalam Pesantren. Jakarta: LP3ES,

Suyuti, Achmad. 2002. Pelatihan Dasar Kepemimpinan (Leadership) dari Aspek dan Moral. Pekalongan: Cinta Ilmu

Thariq As-Suwaidan, dkk. 2005. Melahirkan Pemimpin Masa Depan. Jakarta: Gema Insani,

Wirayuda, Moeftie. 1987. Dimensi Kepemimpinan dalam Manajemen. Jakarta: Balai Pustaka,

Zainuddin, dkk. 1991. Seluk Beluk Pendidikan dari Al-Ghazali. Jakarta: Bumi Aksara, , 1992. Filsafat Pendidikan Islam. Jakarta: Bumi Aksara 